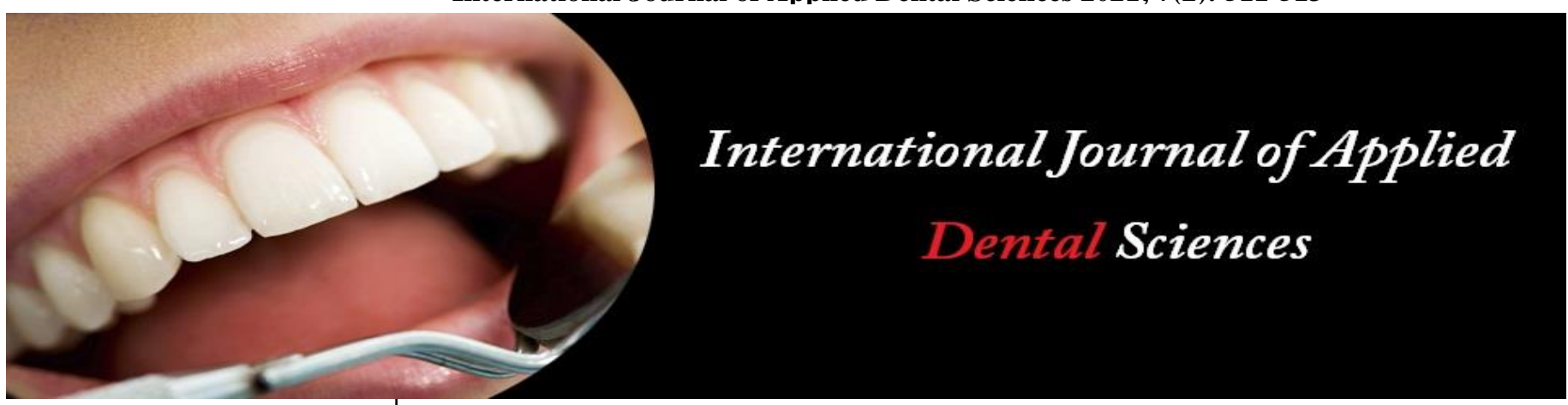

ISSN Print: 2394-7489

ISSN Online: 2394-7497

IJADS 2021; 7(2): 511-513

(C) 2021 IJADS

www.oraljournal.com

Received: 16-02-2021

Accepted: 18-03-2021

Dr. Nidhi Shrivastava Associate Professor,

Department of Dentistry,

Mayo Institute of Medical

Sciences, Barabanki,

Uttar Pradesh, India

Dr. Marisha Bhandari

Reader, Department of

Conservative Dentistry and

Endodontics, Seema Dental

College and Hospital, Rishikesh,

Uttarakhand, India

Dr. Ankur Shrivastava

Professor, Department of

Community Medicine, Mayo

Institute of Medical Sciences,

Barabanki, Uttar Pradesh, India

Corresponding Author:

Dr. Nidhi Shrivastava

Associate Professor,

Department of Dentistry,

Mayo Institute of Medical

Sciences, Barabanki,

Uttar Pradesh, India

\section{Evaluation of oral hygiene awareness and practice among medical students}

\section{Dr. Nidhi Shrivastava, Dr. Marisha Bhandari and Dr. Ankur Shrivastava}

DOI: $\underline{\text { https://doi.org/10.22271/oral.2021.v7.i2h.1256 }}$

\section{Abstract}

The aim of this study is to compare oral-health knowledge, attitude and self-care practice behavior among medical students.

Materials and Methods: A cross sectional study was carried out on $1^{\text {st }}$ year MBBS students. All the students present on the day of data collection were included in the study. Data was collected by pretested questionnaire and analysed using percentages.

Results: Awareness among students about oral hygiene was good. All students in our study were brushing the teeth at least daily with toothbrush and paste. Only few students $(6.92 \%)$ were using fluoride toothpaste and $93.07 \%$ were unaware of fluoride content. Nearly all students restrained from Alcohol Consumption and Tobacco Use. About 23.84\% students had Pain /Discomfort in Past 12 Months and $16.15 \%$ consulted dentist. About 57\% students visited dentist in last 5 years and most common reason was toothache.

Conclusions: The better result among medical students could be due to their better knowledge and socioeconomic conditions. Developing countries show lack of awareness and poor oral hygiene habits among large sections of the population, increasing the risk of oral health problems. More awareness should be created among general population to improve the oral health.

Keywords: awareness, oral hygiene, dental, medical health students

\section{Introduction}

Oral diseases are a major public health concern owing to their high prevalence and their effects on the individual's quality of life ${ }^{[1]}$. The possible etiological factors leading to these oral diseases are genetic predispositions, developmental problems, poor oral hygiene and traumatic incidents ${ }^{[2]}$. Oral hygiene behavior and seeking oral health care depend on a number of factors. People comply better with oral

health care regimens when informed and positively reinforced. Lack of information is among the reasons for non adherence to oral hygiene practices. Further, oral health attitude and beliefs are significant for oral health behavior ${ }^{[3]}$. Keeping a healthy oral profile requires joint efforts from the dentist as well as the

patient himself. One of the most important factors that decide the dental health of a population is the outlook of its people toward their dentition ${ }^{[4]}$.

Oral health knowledge is considered to be an essential prerequisite for health related behavior, although only a weak association seems to exist between knowledge and behavior in crosssectional studies, nevertheless studies have shown that there is an association between knowledge and better oral health ${ }^{[5]}$.

Hence the present study was conducted to evaluate oral hygiene awareness and dental health problems in medical students.

\section{Methods}

The study was conducted at a private medical college in Uttar Pradesh. This was a cross sectional study and purposive sampling method was used to select 1st year MBBS students as study subjects. All the students who were willing to participate were included in the study. Those who were not willing to participate were excluded from study. After taking their informed consent total of 130 students present on the day of data collection were included in 
the study. Data was collected by pretested questionnaire and analysed using percentages.

\section{Results}

Table 1: Awareness about oral hygiene

\begin{tabular}{|c|c|c|c|}
\hline & Response & Number & Percentage \\
\hline \multirow[t]{4}{*}{ State of your teeth } & Very Good & 24 & 18.46 \\
\hline & Good & 81 & 62.30 \\
\hline & Average & 20 & 15.38 \\
\hline & Poor & 5 & 3.84 \\
\hline \multirow[t]{3}{*}{ Brushing of teeth } & Once a day & 108 & 83 \\
\hline & Twice a day & 19 & 14.61 \\
\hline & $\begin{array}{l}\text { More than } \\
\text { twice a day }\end{array}$ & 3 & 2.3 \\
\hline \multirow[t]{4}{*}{$\begin{array}{c}\text { How do you brush } \\
\text { your teeth }\end{array}$} & Toothbrush & 130 & 100 \\
\hline & Wooden stick & & \\
\hline & Chewstick & & \\
\hline & Charcoal & & \\
\hline \multirow[t]{2}{*}{ Use of toothpaste } & Yes & 130 & 100 \\
\hline & No & & \\
\hline \multirow[t]{3}{*}{$\begin{array}{c}\text { Use of fluoride } \\
\text { toothpaste }\end{array}$} & Yes & 9 & 6.92 \\
\hline & $\mathrm{No}$ & & \\
\hline & Don't know & 121 & 93.07 \\
\hline \multirow[t]{2}{*}{ Tobacco use } & Yes & 3 & 2.30 \\
\hline & No & 127 & 97.69 \\
\hline \multirow[t]{2}{*}{$\begin{array}{c}\text { Alcohol } \\
\text { consumption }\end{array}$} & Yes & & \\
\hline & No & 130 & 100 \\
\hline
\end{tabular}

Table 2: Dental Health Problems

\begin{tabular}{|c|c|c|c|}
\hline & Response & Number & Percentage \\
\hline Last visit to dentist & $0-12$ months & 21 & 16.15 \\
\hline & $>1$ year & 24 & 18.46 \\
\hline & $>$ 2years & 6 & 4.61 \\
\hline Reason for last dentist visit & P5years & 23 & 17.69 \\
\hline & Treatment & 36 & 43.07 \\
\hline & $\begin{array}{c}\text { Routine } \\
\text { checkup }\end{array}$ & 15 & 11.53 \\
\hline & $\begin{array}{c}\text { Don't } \\
\text { remember }\end{array}$ & 6 & 4.61 \\
\hline Pain in past 12 months & Yes & 31 & 23.84 \\
\hline & No & 93 & 71.53 \\
\hline & Don't know & 6 & 4.61 \\
\hline Problem of teeth during last & Very often & 6 & 4.61 \\
\hline 12 months & Sometimes & 15 & 11.53 \\
\hline & No problem & 109 & 83.84 \\
\hline
\end{tabular}

\section{Discussion}

Oral hygiene is linked to general awareness regarding healthy habits. All students in our study were brushing teeth at least daily with toothbrush and paste. Similar results were observed in study by Sugumari on dental students. More number of Dental students was brushing teeth twice daily compared to our students. This difference may be due their profession ${ }^{[6,7]}$. These results were in contrast to study by Punitha et al. among rural children where less use of tooth brush $(51 \%)$ and tooth paste $(45 \%)$ was observed mainly due to the lower awareness and economic condition ${ }^{[8]}$.

The frequency of brushing is linked to oral hygiene. Many studies have shown that less frequent tooth brushing was associated with high probability of having poor oral hygiene
[9].

Fluoride is necessary for mineralization of teeth. Many Studies have shown that fluorides prevent and arrest dental caries ${ }^{[10]}$. In our study very few $(6.92 \%)$ students used fluoridated tooth paste and many were unaware of fluoride content of toothpaste whereas Lavanya et al. reported $44.58 \%$ of the dental students and staff, regularly used a fluoridated tooth paste for brushing ${ }^{[6]}$.

Smoking is a life style disease and many young people are addicted to smoking. In our study fortunately $97.69 \%$ students did not use tobacco. Similar results were observed by Lavanya et al. where $93.6 \%$ of the dental students and staff, were found to be non-smokers [6]. According to a study conducted by Gopinath et al. $18.1 \%$ of dental professionals had used tobacco at some point or the other ${ }^{[11]}$. In contrast study conducted by Arthie et al. showed $24 \%$ of dental patients were smokers. Many studies have revealed that smoking has a negative effect on periodontal health ${ }^{[12,13]}$.

Oral health is always a last priority unless it troubles the patient in the form of pain, caries or gum problems etc. People visit dentist only when there is a problem. In our study toothache was the most common reason for visit to dentist. A study conducted in Norway among adults by Sarah et al. showed that only $28 \%$ visited a dentist when in pain or lost a filling and $51 \%$ visited a dentist regularly ${ }^{[14]}$. Another study in Southern Poland among adults by Wojciech et al. observed only $8 \%$ visited a dentist for regular check-up and $53 \%$ visited a dentist only in case of a tooth ache ${ }^{[15]}$.

\section{Conclusion}

The large variation in results could be because of difference in dental awareness among different societies around the world. The better result among medical students could be due to their better knowledge and socioeconomic conditions. Developing countries show lack of awareness and poor oral hygiene habits among large sections of the population, increasing the risk of oral health problems. Thus, more awareness should be created among general population to improve the oral health.

\section{References}

1. Butt AM, Ahmed B, Parveen N, Yazdanie N. Oral Health related quality of life in complete dentures. Pak Oral Dent J 2009;29:397-402. [Google Scholar]

2. Tash RH, O'Shea MM, Cohen K. Testing a Preventive Symptomatic Theory of dental health behavior. Am J Public Health Nations Health 1969;59:514-21. [PMC free article] [PubMed] [Google Scholar]

3. Chander Shekar BR, Reddy C, Manjunath BC, Suma S. Dental health awareness, attitude, oral healthrelated habits, and behaviors in relation to socioeconomic factors among the municipal employees of Mysore city. Ann Trop Med Public Health 2011;4:99-106. [Google Scholar]

4. Dagli RJ, Tadakamadla S, Dhanni C, Duraiswamy P, Kulkarni S. Selfreported dental health attitude and behavior of dental students in India. J Oral Sci 2008;50:267-72. [PubMed] [Google Scholar]

5. Bhat PK, Kumar A, Aruna CN. Preventive oral health knowledge, practice and behavior of patients attending dental institution in Banglore, India. J Int Oral Health 2010;2:1-6. [Google Scholar]

6. Reddy L, Saimadhavi N, Sudhakara Reddy R, Ramesh T, Padma Reddy, Saikiran Ch. Oral hygiene practices and habits among dental students and staff in a dental college India. Cumhuriyet Dent J 2014;17(1):7-13 
7. Elavarasu S, Thangavelu A, Sekar S, Saravanan J, Selvaraj S. Evaluation of oral hygiene practices and awareness among dental students in Namakkal district. Int. Journal of Clinical Dental Science 2014, 5(2).

8. Punitha VC, Sivaprakasam P. Oral hygiene status, knowledge, attitude and practices of oral health among rural children of kanchipuram district. Indian Journal of Multidisciplinary Dentistry 2011;1(2):115-8.

9. Villalobos-Rodelo J, Medina- Solis CE. Socioeconomic and sociodemographic variables associated with oral hygiene status in Mexican school children aged 6 to 12 years. J Periodontal 2007, 816-22.

10. McKelvey VA, Thomson WM. A qualitative study of oral health knowledge and attitudes among staff caring for older people in Dunedin long-term care facilities. New Zealand Dental Journal 2003;99(4):98-103.

11. Gopinath V. Oral hygiene practices and habits among dental professionals in Chennai. Indian J Dent Res 2010;21(2):195-200.

12. Thangavelu A, Elavarasu S, Saravanan J. Oral health practices and awareness among patients at the department of periodontics at J.K.K.N Dental college and hospital, Komarapalayam. IJCDS. 2014;5(1):13-6.

13. Puscasu CG, Totolici I. Study regarding the connection between the oral hygiene status, plaque control methods and the periodontal involvement in a group of adults. OHDMBSC 2007;6(3):12-8.

14. Adekoya SM, Brustad M. Oral health of adults in northern Norway - A pilot study. Norsk Epidemiologi 2012;22(1):31-8.

15. Skorupka W, Zurek K, Kokot T, Nowakowska-Zajdel E, Fatyga E, Niedworok E. Assesment of oral hygiene in adults. Cent Eur J Public Health 2012;20(3):233-6. 